\title{
Major Nutritional Issues in the Management of Parkinson's Disease
}

\author{
Michela Barichella, MD, ${ }^{1}$ Emanuele Cereda, MD, ${ }^{1,2 *}$ and Gianni Pezzoli, MD ${ }^{1}$ \\ ${ }^{I}$ Parkinson Institute, Istituti Clinici di Perfezionamento, Milano, Italy \\ ${ }^{2}$ International Center for the Assessment of Nutritional Status (ICANS), University of Milan, Milan, Italy
}

\begin{abstract}
As with other neurodegenerative diseases, neurologic and nutritional elements may interact affecting each other in Parkinson's disease (PD). However, the long-term effects of such interactions on prognosis and outcome have not been given much attention and are poorly addressed by current research. Factors contributing to the clinical conditions of patients with PD are not only the basic features of $\mathrm{PD}$, progression of disease, and the therapeutic approach but also fiber and nutrient intakes (in terms of both energy and protein content), fluid and micronutrient balance, and pharmaconutrient interactions (protein and levodopa). During the course of PD nutritional requirements frequently change. Accordingly, both body weight gain and loss may occur and, despite controversy, it seems that both changes in energy expenditure and food intake contribute. Nonmotor symptoms play a significant role and dysphagia may be responsible for the impairment of nutritional status and fluid balance. Constipation, gastroparesis, and gastro-oesophageal
\end{abstract}

reflux significantly affect quality of life. Finally, any micronutrient deficiencies should be taken into account. Nutritional assessments should be performed routinely. Optimization of pharmacologic treatment for both motor and nonmotor symptoms is essential, but nutritional interventions and counseling could and should also be planned with regard to nutritional balance designed to prevent weight loss or gain; optimization of levodopa pharmacokinetics and avoidance of interaction with proteins; improvement in gastrointestinal dysfunction (e.g., dysphagia and constipation); prevention and treatment of nutritional deficiencies (micronutrients or vitamins). A balanced Mediterranean-like dietary regimen should be recommended before the introduction of levodopa; afterward, patients with advanced disease may benefit considerably from protein redistribution and low-protein regimens. (c) 2009 Movement Disorder Society

Key words: Parkinson's disease; nutrition; gastrointestinal dysfunction; body weight; diet; levodopa
Several studies have shown a close relationship between nutritional status and neurodegenerative diseases. Similar evidence is shared also by Parkinson's disease (PD). ${ }^{1-15}$

This article is part of the journal's online CME program. The CME activity including form, can be found online at http://www. movementdisorders.org/education/journalcme/

*Correspondence to: Dr. Emanuele Cereda, International Center for the Assessment of Nutritional Status (ICANS), University of Milan, via Botticelli 21, 20133 Milan, Italy.

E-mail: emanuele.cereda@virgilio.it

Potential conflict of interest: The authors also certify that there are no affiliations with or involvement in any organization or entity with a direct financial interest in the subject matter or materials discussed herein.

Received 21 November 2008; Revised 17 June 2009; Accepted 20 June 2009

Published online 18 August 2009 in Wiley InterScience (www. interscience.wiley.com). DOI: 10.1002/mds.22705
PD is a chronic neurodegenerative disorder that is due mainly to the progressive degeneration of the nigrostriatal dopaminergic pathway. ${ }^{16}$ Bradykinesia, resting tremor, rigidity, curved posture, shuffling gait, and postural instability are its cardinal symptoms and signs, which, together with the long-term complications of dopaminergic treatment (motor blocks and dyskinesias), progressively lead to severe disability. ${ }^{17}$ Along with this, not only motor but above all nonmotor complications, together with some available treatments, contribute substantially to the changes in nutritional status during the course of the disease..$^{8,13,14,18-24}$ Thus, adjustment of nutritional intake should always be taken into consideration.

It is now accepted that a nutritional assessment should be included in the work-up of patients with PD. Nutritional advice may contribute to the amelioration 
TABLE 1. Studies investigating the association between body weight, adiposity, and the risk for Parkinson's disease (PD)

\begin{tabular}{|c|c|c|c|}
\hline Study (nation) & $\begin{array}{l}\text { Follow-up } \\
\text { duration, yr }\end{array}$ & Sample size [cases] & Reported evidence \\
\hline $\begin{array}{l}\text { Hu et al. } \\
\quad \text { (Finnish) }\end{array}$ & 18.8 & $\begin{array}{l}22.367 \text { males, } \\
23.439 \text { females [272M:254F] }\end{array}$ & $\begin{array}{l}\text { Increasing BMI was associated with } \\
\text { higher PD risk in both sexes; the } \\
\text { association with early-onset PD (aged at } \\
\text { diagnosis }<65 \text { yr) was even stronger }\end{array}$ \\
\hline $\begin{array}{l}\text { Abbott et al. } \\
\text { (Japanese Americans) })^{3}\end{array}$ & 30 & 7.990 males [137] & $\begin{array}{l}\text { Increasing adiposity measured by triceps } \\
\text { skinfold thickness was associated with an } \\
\text { elevated risk of early-onset (age at diagnosis } \\
<65 \mathrm{yr} \text { ) and late-onset (aged at diagnosis }>65 \mathrm{yr} \text { ) } \\
\text { PD. Associations between BMI and subscapular } \\
\text { skinfold thickness were weaker }\end{array}$ \\
\hline $\begin{array}{l}\text { Chen et al. } \\
\text { (Americans) }^{5}\end{array}$ & $12-14$ & $\begin{array}{l}47.700 \text { males, } \\
117.062 \text { females [249M: } 202 \mathrm{~F}]\end{array}$ & $\begin{array}{l}\text { In the overall study cohort, neither baseline BMI } \\
\text { nor early adult BMI nor body fat distribution } \\
\text { (WC and WHR) was associated with PD risk. } \\
\text { However, among never smokers the highest quintiles } \\
\text { of central fat distribution indexes were associated with } \\
\text { PD risk in both sexes }\end{array}$ \\
\hline $\begin{array}{l}\text { Logroscino et al. } \\
\text { (Americans) }^{27}\end{array}$ & 20 & 10.812 males $[106 \mathrm{M}]$ & $\begin{array}{l}\text { In elderly subjects (mean cohort age at inclusion } 67.7 \mathrm{yr} \text { ), } \\
\text { increasing BMI was not associated with PD risk. This may } \\
\text { be due to weight loss preceding clinical diagnosis, as subjects } \\
\text { losing } 0.5 \text { units of BMI per decade had a significantly } \\
\text { increased risk }\end{array}$ \\
\hline
\end{tabular}

BMI, body mass index; WC, waist circumference; WHR, waist-to-hip ratio.

of symptoms and health-related quality of life (e.g., controlled-protein dietary regimens for patients with motor fluctuations). ${ }^{25,26}$ The objective of this review is to point out the major nutritional issues that should be taken into consideration in the management of patients with PD and to describe the nutritional therapeutic options that are available. The issues are discussed from a clinical rather than a pathophysiologic perspective. Few clinical trials have been performed on nutritional issues in PD, and so most of the therapeutic options are based on indirect evidence and on speculation. The inadequacy of clinical evidence will be stressed whenever appropriate and suggestions for further research will be made.

\section{BODY WEIGHT}

As in other neurodegenerative disorders, such as Alzheimer's syndromes, ${ }^{1}$ longitudinal studies have suggested that middle-age adiposity, especially when it involves the visceral body fat compartment, may be a risk factor for $\mathrm{PD}^{2,3,5}$ (Table 1). However, studies investigating the independent effect of the complications of obesity, such as diabetes and hypercholesterolemia, as risk factors for PD have provided inconsistent results (Table 2). ${ }^{28-34}$ Other studies have reported that increase in body mass index [BMI $=$ weight (kilogram)/height (square meter)] is unrelated to PD. ${ }^{5,27}$ The lack of consistency of these studies may be due to the strong confounding effects of dietary factors or weight loss preceding clinical diagnosis. ${ }^{5}$ However, during the course of patients with PD may experience both weight loss and gain (Fig. 1). This is consistent with the results of a recent study in the Italian population, which revealed that the prevalence of obesity among patients with PD is about $50 \%$ higher than that in the general reference population. ${ }^{7}$

\section{Weight Loss}

Progressive weight loss down to overt undernutrition is a major feature of PD progression. .,12,35,36 $^{\text {Weight }}$ loss, especially fat mass loss, ${ }^{20,37}$ is believed to be a continuous process that starts several years before diagnosis. ${ }^{37}$ It worsens as the disease progresses, along with poor motor control (fluctuations) and poor response to treatment. ${ }^{6-8}$ The observation that weight loss frequently precedes the diagnosis, despite a tendency to increase energy intake, supports the hypothesis that it is mainly due to an increase in energy expenditure. $^{18,37-39}$ However, it is reasonable to argue that both energy intake and expenditure contribute to weight loss during the course of the disease.

Resting energy expenditure studies by indirect calorimetry have reported that calorie consumption is significantly increased in both untreated and optimally treated patients with PD. ${ }^{19,20,38}$ Rigidity and dyskinesias may be responsible for increases in energy 
TABLE 2. Studies investigating the association between cardiovascular risk factors and the risk for Parkinson's disease (PD)

\begin{tabular}{|c|c|c|c|c|}
\hline Study (ethnicity) & $\begin{array}{l}\text { Follow-up } \\
\text { duration, yr }\end{array}$ & $\begin{array}{l}\text { Sample size } \\
\text { [cases] }\end{array}$ & $\mathrm{CV}$ risk factor & Reported evidence \\
\hline $\begin{array}{l}\text { Hu et al. } \\
\quad(\text { Finnish })^{29}\end{array}$ & 18 & $\begin{array}{l}25.188 \text { males, } \\
26.374 \text { females } \\
{[324 \mathrm{M}: 309 \mathrm{~F}]}\end{array}$ & Diabetes & $\begin{array}{l}\text { Increasing BMI was associated with higher } \\
\text { PD risk in both sexes; the association with } \\
\text { early-onset PD (aged at diagnosis }<65 \mathrm{yr} \text { ) } \\
\text { was even stronger }\end{array}$ \\
\hline $\begin{array}{l}\text { Driver et al. } \\
\quad \text { (Americans) }^{32}\end{array}$ & 23 & 21.841 males [566] & Diabetes & $\begin{array}{l}\text { Increasing adiposity measured by triceps skinfold } \\
\text { thickness was associated with an elevated risk of } \\
\text { early-onset (age at diagnosis }<65 \mathrm{yr} \text { ) } \\
\text { and late-onset (aged at diagnosis } \\
>65 \mathrm{yr} \text { ) PD. Associations between BMI and subscapular } \\
\text { skinfold thickness were weaker }\end{array}$ \\
\hline \multirow[t]{3}{*}{$\begin{array}{l}\text { Simon et al. } \\
\text { (Americans) }^{30}\end{array}$} & \multirow[t]{3}{*}{23} & \multirow{3}{*}{$\begin{array}{l}50.833 \text { males, } \\
121.046 \text { females } \\
{[264 \mathrm{M}: 266 \mathrm{~F}]}\end{array}$} & Diabetes & $\begin{array}{l}\text { Updated self-reported diagnosis of diabetes was unrelated } \\
\text { to increased PD risk }\end{array}$ \\
\hline & & & Hypertension & $\begin{array}{l}\text { Updated self-reported diagnosis of high blood pressure } \\
\text { (systolic }>160 \mathrm{mmHg} \text { and/or diastolic }>90 \mathrm{mmHg} \\
\text { and/or use of antihypertensive medications) } \\
\text { was unrelated to PD risk. }\end{array}$ \\
\hline & & & Total cholesterol & $\begin{array}{l}\text { Updated self-reported hypercholesterolemia was unrelated } \\
\text { to PD risk although this may modestly decline with } \\
\text { increasing blood cholesterol levels }\end{array}$ \\
\hline $\begin{array}{l}\text { Hu et al. } \\
\qquad(\text { Finnish })^{31}\end{array}$ & 18 & $\begin{array}{l}24.773 \text { males, } \\
26.153 \text { females } \\
{[321 \mathrm{M}: 304 \mathrm{~F}]}\end{array}$ & Total cholesterol & $\begin{array}{l}\text { Increasing total cholesterol is associated with PD risk.. } \\
\text { However, the association was inconsistent in subjects } \\
\text { aged } \geq 55 \text { years at baseline. Ongoing chronic disorders } \\
\text { might have masked (reducing levels ?) the effect in } \\
\text { this subgroup. }\end{array}$ \\
\hline $\begin{array}{l}\text { de Lau et al. } \\
\text { (Dutch) }^{34}\end{array}$ & 9 & $\begin{array}{l}2.654 \text { males, } \\
3.811 \text { females } \\
{[46 \mathrm{M}: 41 \mathrm{~F}]}\end{array}$ & Total cholesterol & $\begin{array}{l}\text { In elderly subjects (mean age at inclusion } 69.0 \text { years) } \\
\text { the authors observed a dose-effect relationship } \\
\text { between increasing total cholesterol levels and } \\
\text { decrased risk of PD. In gender pre-specified subgroup } \\
\text { analyses the association was restricted to women }\end{array}$ \\
\hline $\begin{array}{l}\text { Huang et al. } \\
\qquad{\text { (Japanese-Americans) })^{33}}^{3}\end{array}$ & 9 & 3.233 males [41] & LDL-cholesterol & $\begin{array}{l}\text { In subjects aged } 71-75 \text { years at inclusion, the authors } \\
\text { detected a dose-effect relationship between decreasing } \\
\text { LDL cholesterol levels and increased risk of PD. } \\
\text { The basis of this association needs to be clarified }\end{array}$ \\
\hline
\end{tabular}

BMI, body mass index; WC, waist circumference; WHR, waist-to-hip ratio.

expenditure, but they cannot be considered to be the sole cause of a highly negative energy balance $(\sim 400$ $\mathrm{Kcal} /$ day). Motor symptoms can frequently restrict activities of daily living related to food intake, such as cooking or shopping ${ }^{35}$; this supports the hypothesis that reduced energy intake may also have a role. Indeed, a recent 3-year longitudinal study showed that impairment of nutritional status, assessed using the Mini Nutritional Assessment tool, was mainly due to poor nutritional habits. ${ }^{8}$ However, increasing energy intake to compensate for the increase in energy expenditure was not effective in preventing weight loss. This indicates that other factors contribute to the phenomenon (e.g., malabsorption). ${ }^{18,40}$

Decline in cognitive functions may also play a role, ${ }^{1,12,36}$ because it can affect interest in food through hyposmia and eating habits. Individuals with memory impairment may forget to eat and physical disability may impede feeding in the absence of a caregiver. ${ }^{1}$ Indeed, neurodegeneration and cognitive impairment have been associated with poor nutritional status also in PD. ${ }^{12,41}$

\section{Weight Gain}

Surgical procedures (pallidotomy, deep brain stimulation) are associated with significant weight gain. $^{22,23,42,43}$ A number of concurrent factors are believed to contribute, especially disease improvement and the resolution of levodopa (L-dopa)-related complications (dyskinesias). ${ }^{22,23,42}$ Increase in appetite has been reported ${ }^{44}$ and hormonal (e.g., insulin and growth hormone) balance may be restored (see Body Weight and Metabolic Derangements section). ${ }^{6}$

Also dopamine agonists, such as pramipexole, may produce weight gain mediated by similar mechanisms to those described earlier (induction of compulsive eating or a positive effect on depressive symptoms) in patients with PD with poor quality of life. ${ }^{21,44,45}$

Moreover, regardless of the treatment provided, also abnormal neuroendocrine regulation (e.g., corticotro- 


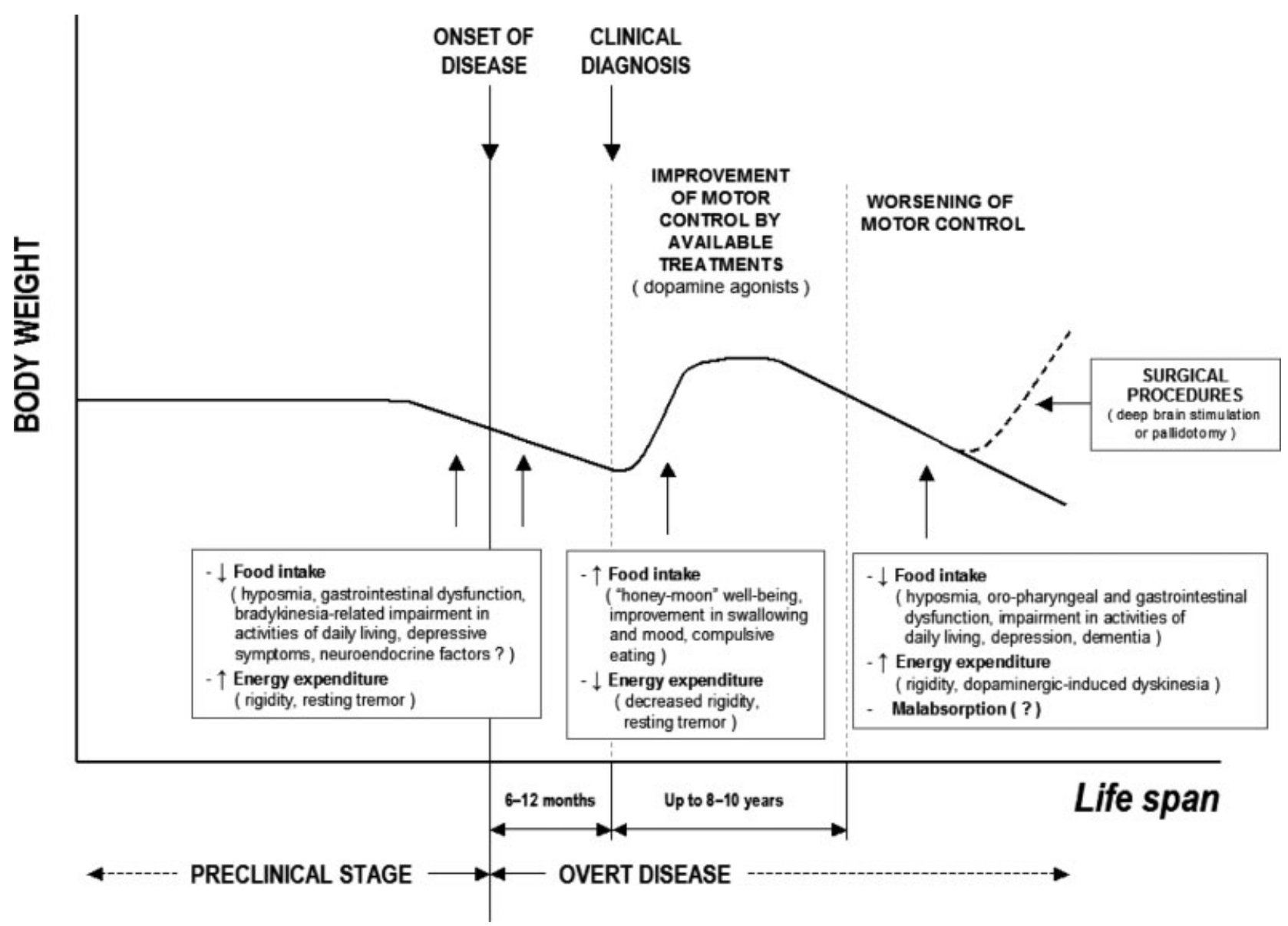

FIG. 1. Possible natural history of body weight in patients with PD.

phin-releasing hormone and orexin-related signaling pathways) is believed to play a role in inducing weight gain. ${ }^{46}$

\section{Body Weight and Metabolic Derangements}

Long-term L-dopa treatment, the mainstay of PD management, induces hypersecretion of both insulin and growth hormone $(\mathrm{GH}){ }^{47}$ This hormonal derangement can trigger a lipolytic cycle that is thought to be responsible for the increase in basal metabolic rate ${ }^{48}$ and weight loss. Disruption of this derangement due to neurosurgical procedures or L-dopa dosage reduction could explain weight gain. Glucose intolerance, which is closely related to adiposity, ${ }^{4}$ is often found in $\mathrm{PD}^{49,50}$ and may also be a risk factor for $\mathrm{PD}^{29}$ The true interrelationship among these factors is not known. It is reasonable to argue that genetic and environmental factors interact during ageing and that glucose intoler- ance might occur before the onset of PD or become evident after the introduction of L-dopa.

The association between weight changes/control and glucose intolerance/diabetes in PD, and the effect on outcome have never been investigated. Routine screening for glucose intolerance seems to be advisable.

\section{Weight Changes and Implications for Health Status}

The effect of weight changes on patient prognosis and disease progression is still unknown. Non-PD disease-related malnutrition has a negative impact on the prognosis of the patient, ${ }^{51}$ and in some neurodegenerative diseases, such as Alzheimer's disease, it may be associated with accelerated progression of the disease. ${ }^{10}$ It cannot be excluded that a high initial body weight may counterbalance progressive weight loss, thus slowing physical deterioration. Low BMI certainly is associated with a reduction in bone mineral mass 
density, and a high risk of fractures that can be secondary to vitamin D deficiency ${ }^{52,53}$ Noteworthy is the quality of weight gain in patients with PD undergoing deep brain stimulation, which seems to differ according to gender, with men gaining primarily fat-free mass and women adipose tissue. ${ }^{42}$ Abdominal fat mass significantly increases after neurosurgery in both sexes, ${ }^{22,42}$ and the prevalence of adverse fat distribution is high in $\mathrm{PD}^{7}$ - a reason for concern given the risk of complications, such as cardiovascular disease, diabetes, and dementia syndromes, related to this body fat compartment. ${ }^{4}$

Studies exploring changes and abnormalities in cardiometabolic parameters have not been performed. Overweight in PD seems to be associated with significant rates of dyslipidemia (52.2\%), arterial hypertension (28.3\%), and impaired glucose control $(17.5 \%)^{7}$

\section{GASTROINTESTINAL DYSFUNCTION}

Gastrointestinal dysfunction may affect the patient's well-being, treatment optimization, and nutritional balance (Fig. 2). Given the difficulty in performing repetitive movements and the presence of jaw tremor and/or rigidity, chewing may be impaired, also on account of concurrent tooth damage. ${ }^{54}$ Prolonged feeding procedures and fatigue, secondary also to difficulties in swallowing $^{55}$ can lead to meal interruption and inadequate food intake. Progressive limitation or avoidance of some products may lead to deficiencies, initially in micronutrients and subsequently in energy. ${ }^{35}$

\section{Dysphagia}

Dysphagia is believed to play a role in weight loss. ${ }^{6,8,37,56}$ However, according to some authors it makes a minor contribution, because it usually occurs in the advanced phases of the disease, ${ }^{57}$ although sometimes it is present at onset. ${ }^{58}$ Various investigations (electrophysiology, manometry, videofluorography) have detected functional alterations of both oropharyngeal and oesophageal motility in about 60 to $80 \%$ of patients; such alterations may be asymptomatic. $^{58-62}$ The risk of aspiration due to upper oesophageal dysmotility should be taken into account and routine assessment of such abnormalities may be suggested. Simple tools, based on clinical parameters (BMI, Hoehn and Yahr stage, drink and food retention in the mouth) or questionnaires addressing selfreported perception of swallowing disturbances, have recently been proposed for patient assessment, provided that their sensitivity and specificity $(\geq 80 \%)$ are adequate. Their use in clinical practice should be extensively investigated and validated. ${ }^{63,64}$

Dysphagia may be for both solids and liquids. The former may be responsible for energy imbalance ${ }^{56}$ the latter is usually associated with dehydration and risk of aspiration, as well as with social and psychological discomfort, mainly due to saliva retention in the mouth associated with drooling. ${ }^{64,65}$

Regarding the pathophysiology of oesophageal dysfunction, it is believed that the underlying neurodegenerative mechanisms in the central and the peripheral nervous system such as the brainstem nuclei and Auerbach's and Meissner's plexuses, are similar. ${ }^{108}$ The initial location and exact timing of this pathological process are still unknown. The existence of a continuous chain of susceptible neurons, extending from the enteric to the central nervous system, has recently been demonstrated. The evidence supports the hypothesis of a centripetal progression of the neurodegenerative process. ${ }^{67}$

The involvement of oesophageal motility results not only in impaired peristalsis but also in abnormalities in lower sphincter activity contributing to gastro-oesophageal reflux. This complication is more likely to occur in the presence of gastric dysfunction. ${ }^{68}$

\section{Gastric Dysfunction}

Impaired gastric emptying is commonly reported in both early and advanced patients with PD. ${ }^{69,70}$ It seems to be related to severe motor function impairment and motor fluctuations, typical of disease progression, ${ }^{70}$ but the basis of the association is not fully understood. Delayed gastric emptying may prolong the exposure of L-dopa to dopa decarboxylase in the gastric mucosa and delay the arrival of the drug into the duodenum, reducing its absorption from the gut and, consequently, its efficacy. ${ }^{71}$ However, it cannot be excluded that poor motor control and gastric dysfunction in advanced PD are simultaneous manifestations of a neurodegenerative process affecting both the central (dorsal motor nucleus of the vagal nerve) and peripheral nervous system. ${ }^{58,67,69}$ This hypothesis is consistent with the results of a trial reporting that L-dopa ethylester, a very soluble L-dopa prodrug that passes through the stomach very rapidly, does not provide any advantage in reducing total daily time in ON. ${ }^{109}$ Finally, alterations in gastric and intestinal motility may be associated with abdominal distension, discomfort, nausea and early sa- 
tiety, and bloating may reduce enjoyment of food and energy intake. Weight loss may be a consequence.

\section{Small Intestine Dysfunction}

Very little is known about small intestine function in PD. Dopaminergic enteric activity is believed, once again, to be involved. Changes in motility prolong orocaecal transit. ${ }^{58,72}$ Such changes might be associated with bacterial overgrowth in the small intestine and malabsorption due to both specific and nonspecific alterations of the enterocyte brush border membrane. ${ }^{48}$

\section{Constipation}

Constipation (less than three bowel movements per week) is the most commonly reported (50-80\%) gastrointestinal symptom in PD. ${ }^{13,27}$ It can occur during both preclinical and clinical stages of the disease ${ }^{13,68,73}$ and worsens with disease progression. ${ }^{74}$ Barium studies have shown that prolonged colon content transit time is the physiological basis of both symptomatic and asymptomatic constipation. ${ }^{75}$ Most patients experience only mild discomfort and distension, but the risk of life-threatening complications, such as megacolon and pseudo or true obstruction resulting in bowel perforation should be taken into account and prevented. ${ }^{75}$ Dysmotility may be related to poor fiber and fluid intake or reduced physical activity. ${ }^{75,77}$ Some authors point out that the neurodegenerative process in the enteric nervous system may be a potential target for future therapies. $58,78,79$

\section{Therapeutic Approaches}

Gastrointestinal dysfunction responds poorly to current treatment (both medical and surgical) for motor symptoms. Significant improvement seems to be achievable only in the oral and pharyngeal phases of swallowing, which depend mainly on the function of the medullary pattern generator network and the outflow of the basal ganglia. ${ }^{80-82}$

The efficacy of alternative pharmacological treatments has been investigated, but few clinical trials have been performed. Some medications have been withdrawn, and the use of others has been discouraged after initial testing due to adverse effects.

To improve dysphagia, no universal approach is available. The optimization of motor symptom control should always be given priority, and both surgical and pharmacological options have been investigated in regard to this. L-dopa and apomorphine can improve the early phases (oral and pharyngeal) of deglutition, also by restricting total swallowing time. $^{81,82}$ The percutaneous injection of botulinum toxin or the resection of the cricopharyngeal muscle have been considered only in selected patients ${ }^{83,84}$ and benefit from neurosurgical stimulation have been reported. ${ }^{81}$

The use of prokinetic agents has been suggested for the management of delayed gastric emptying. To date, only domperidone by oral route has proved to be both effective and safe. ${ }^{58}$ Unlike metoclopramide, another $\mathrm{D}_{2}$ (dopamine type 2) receptor blocker (antagonist), it is less likely to cross the blood-brain barrier and exacerbate parkinsonism. A similar adverse effect has been reported with the use of cisapride and the main concern with this drug is related to the risk of fatal arrhythmias and sudden death. The use of prokinetics in the treatment of constipation is doubtful.

Irritant laxatives are reserved to selected patients, whereas stool softeners, such as polyethylene glycol solutions (Macrogol) or lactulose, are more widely used and better tolerated. ${ }^{85,86}$ There is evidence supporting the use of probiotics and prebiotics in the elderly, ${ }^{87}$ but their use has never been investigated in patients with PD. Finally, a recent pilot randomized, controlled trial has suggested that a 5-HT4 (5-hydroxytryptamine subtype-4 receptor) partial agonist (tagaserod) is both efficacious and safe. ${ }^{88}$

Based on the considerations above, there are few pharmacological options for the management of gastrointestinal dysfunction. Nevertheless, a number of nutritional recommendations could be provided to improve symptoms, discomfort and quality of life. The suggestions rest on limited evidence mostly collected in other populations of patients because clinical trials in PD are still lacking.

\section{NUTRITIONAL TREATMENT: PRESENT AND FUTURE}

Body weight control is crucial in our century, as the consequences of malnutrition, both in terms of excess and deficiency, are now well known. In patients with PD, this could be achieved through adjustments in nutritional intake, designed to improve motor and nonmotor symptoms at the same time.

At present, there is no evidence to support or refute the efficacy of nonpharmacological nutritional therapy for gastrointestinal dysfunction, which has proved to be a complication associated with impaired quality of life and nutritional status. ${ }^{5,85,90,94}$ 


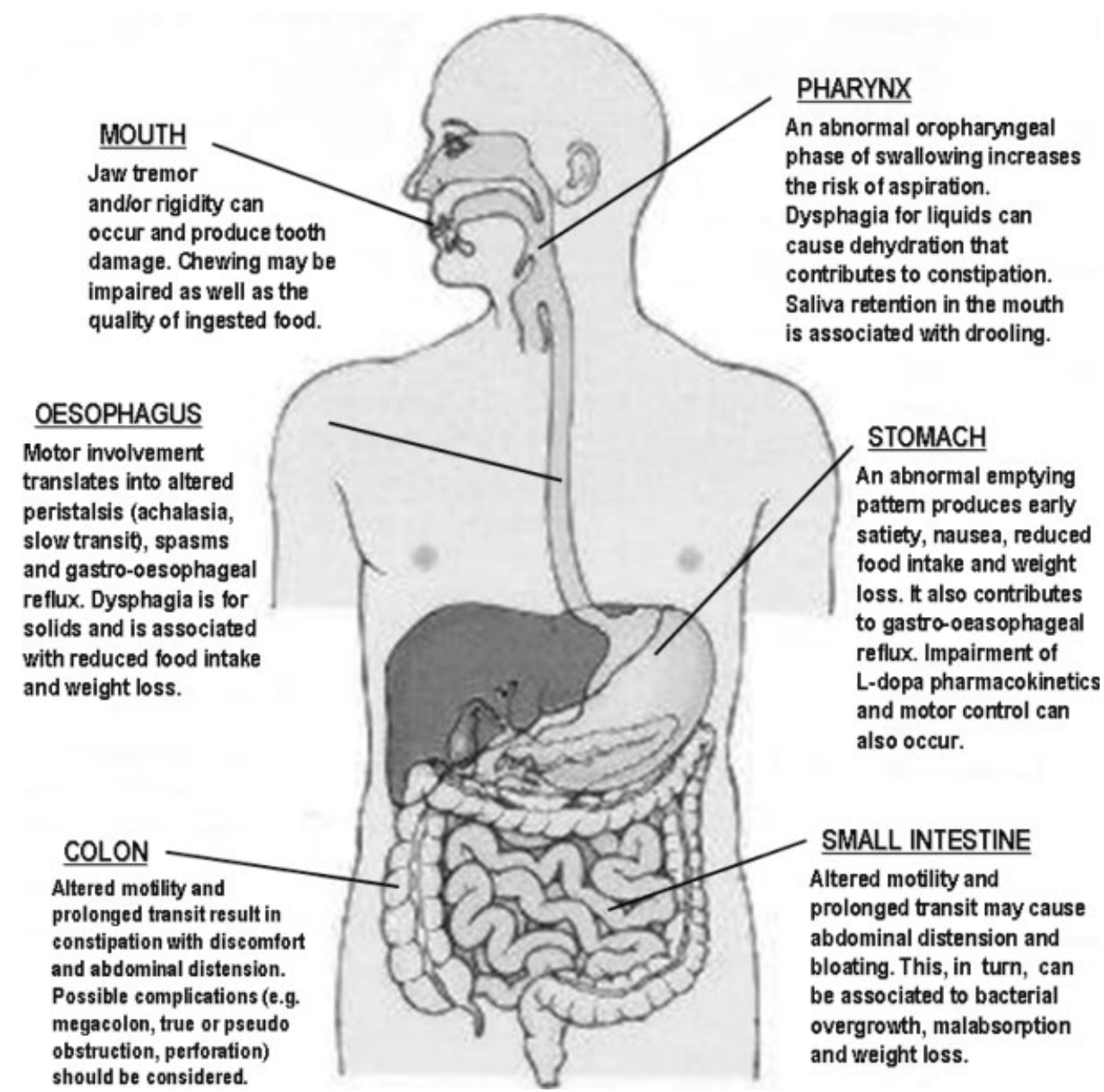

FIG. 2. Major gastrointestinal problems of patients with PD.

\section{Options for Dysphagia}

Thickening procedures (e.g., for beverages and soups) are generally recommended to increase fluid intake and to prevent aspiration pneumonia. ${ }^{89,90}$ Postural arrangements may also be useful. A large randomized clinical trial, comparing the impact of three interventions (chin-down posture and nectar-or honey-thickened liquids) on liquid aspiration in PD, and dementia patients has been published. Unfortunately, definitive conclusions could not be drawn, neither about the superiority nor about the usefulness of any procedure due to the lack of a no-treatment control group. ${ }^{95}$ Texture-modified diet and the use of thickened whole-formulations and ready-to-eat foods could be taken into account to obtain better timing and safer swallowing in patients with PD. ${ }^{89,90,95} \mathrm{~A}$ dietician should monitor the effectiveness of the measures and the severity of symptoms. Long-term inability to achieve adequate nutrition is an established indication for gastrostomy. ${ }^{93}$

\section{Options for Gastric and Intestinal Dysfunction}

Theoretically the nutritional management of gastric dysfunction may result in several benefits, such as better L-dopa absorption and dosage reduction. The pattern of gastric emptying may depend on meal composition (macronutrients) with fats and high-fiber foods usually producing a delay. ${ }^{96,97}$

Changes in requirements may be rapidly adapted by adjusting fat intake. However, high quality carbohydrates (starch) should be preferred, in view of their effect on glucose tolerance. ${ }^{98}$

Fiber plays an important role in the management of constipation and adequate consumption, at least 30 to $35 \mathrm{~g}$ daily, together with appropriate fluid intake (at least $1,500 \mathrm{~mL}$ daily) could be encouraged. ${ }^{73,86}$ Moder- 
ate fat and adequate fiber intake could be beneficial also for gastroesophageal reflux. ${ }^{99}$

Physical activity can increase bowel movements and reduce reflux episodes, ${ }^{86,92}$ producing benefits also with regard to body weight, physical functions, healthrelated quality of life, mood, strength, balance, and gait speed. This practice could be proposed to patients with PD but optimal exercise interventions (duration and components) for the various disease's stages have not been established. ${ }^{100}$

\section{Dietary Management of L-dopa-Treated Patients}

Dietary neutral aminoacids and L-dopa compete for transportation through a specific active-transport system in the small intestine and at the blood-brain barrier. The consequences of this competition are suboptimal clinical response, especially motor block. Accordingly, diet manipulation focused on protein intake could be considered. A diet with a normal protein content ( $15 \%$ of total energy) can be proposed to patients in the initial stages of $\mathrm{PD}$, whereas low-protein and protein-redistribution dietary regimens (10\% of total energy) are more suitable for patients with PD with advanced disease. These are based on the restriction of the protein content of breakfast and lunch and the consumption of a high-protein meal in the evening. ${ }^{101}$

Patients are told to take their medication about 30 minutes before meals to maximize absorption. Nevertheless, there is evidence suggesting that the dietary habits of patients with advanced PD and/or motor fluctuations should always be checked, as usual protein intake often is $50 \%$ higher than the recommended daily allowance (1.2 vs $0.8 \mathrm{~g} / \mathrm{kg}$ ideal body weight). ${ }^{102}$

Patients should be monitored to avoid L-dopa overdose-related side effects. ${ }^{25}$ Moreover, long-term adherence to this kind of regimen may induce weight loss and nutritional deficiencies (e.g., protein, calcium, iron, phosphorus, riboflavin, niacin). ${ }^{25,26}$ Logistic difficulties and poor palatability have been also pointed out. ${ }^{103}$ These shortcomings appear to have been overcome by the use of low-protein foods designed for patients with chronic renal failure. ${ }^{26}$

\section{Micronutrients}

The evidence related to micronutrients is still limited. Deficiencies in micronutrients seem to be associated with eating difficulties and to occur before deficiencies in energy and protein. Low plasma levels of some of them, such as iron, zinc, vitamins $\mathrm{A}$ and $\mathrm{E}$ may be secondary to both reduced intake and increased

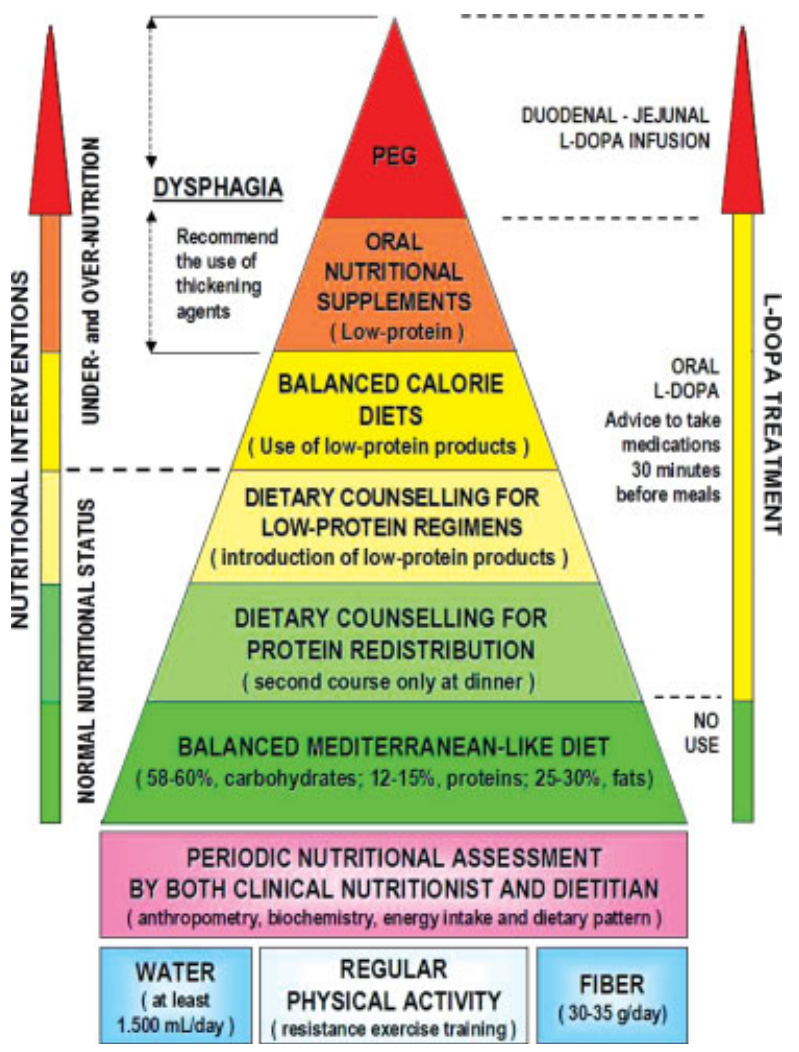

FIG. 3. A potential nutritional treatment pyramid for patients with $\mathrm{PD}$ in relation to stage of disease.

requirements due to oxidative stress. ${ }^{27}$ Low intakes of antioxidant vitamins (e.g., A, C, and E) might increase the risk of PD, but intervention studies do not support the use of oral supplements. ${ }^{104}$ Folate may be given to patients with L-dopa-related hyperhomocysteinemia to counteract the hypothetical related risk of heart disease, stroke and dementia. ${ }^{105}$ However, there are no studies demonstrating an increased risk of vascular disease in patients with PD with high homocysteine levels, whereas very recent case-control studies have reported conflicting associations with cognitive impairment. ${ }^{106,107}$ Dietary regimens should also cover calcium and vitamin D requirements. ${ }^{53}$

\section{General Dietary Advice}

The long-term follow-up of the patient with PD should include assessments designed to address all the issues discussed earlier. An algorithm for the dietary management of patients with PD is proposed in Figure 3.

Regular physical activity is advisable. Before the introduction of L-dopa, a balanced Mediterranean-like diet model could be proposed. ${ }^{110}$ After the introduction 
TABLE 3. Major nutritional issues deserving further investigation

\begin{tabular}{cl}
\hline $\begin{array}{c}\text { PD progression } \\
\text { and outcome }\end{array}$ & $\begin{array}{c}\text { Nutritional status, weight changes } \\
\text { (and weight control); } \\
\text { cardiovascular risk factors } \\
\text { (hypertension, diabetes and hypercolesterolemia); } \\
\text { dietary pattern and protein-redistribution diet }\end{array}$ \\
$\begin{array}{c}\text { Neurosurgical procedures, weight gain, } \\
\text { affects }\end{array}$ & $\begin{array}{l}\text { and the occurrence of overweight-related } \\
\text { cardiovascular risk factors; long-term adherence } \\
\text { to protein-redistribution dietary regimen }\end{array}$ \\
& $\begin{array}{l}\text { and nutritional status; behavioral } \\
\text { and lifestyle changes in the management } \\
\text { of gastrointestinal dysfunction } \\
\text { (dysphagia, gastro-oesophageal reflux, } \\
\text { gastric emptying and constipation) }\end{array}$ \\
&
\end{tabular}

of L-dopa, the protein-redistribution dietary regimen can improve its absorption. In the later stages of the disease, patients could benefit from the introduction of low-protein products (rusks, bread, pasta, and other snacks). Exact amounts of food can be prescribed to induce body weight gain or loss. In the presence of overt malnutrition or the risk of its development, the use of energy-dense oral nutritional supplements designed for renal patients may be taken into account, as well as texture-modified diets and thickening agents for concurrent dysphagia. Finally, when oral feeding cannot maintain adequate energy intake any longer, percutaneous endoscopic gastrostomy is clearly indicated. $^{93}$

\section{CONCLUSIONS}

The impact of nutritional management on the course of the disease has not been elucidated and should be investigated (Table 3).

Optimization of pharmacologic treatment for both motor and nonmotor symptoms is essential. Nutritional interventions and counseling should be planned at the same time with regard to the following.

- Nutritional balance designed to prevent body weight changes

- Optimization of L-dopa pharmacokinetics by avoiding interaction with nutrients, such as dietary proteins

- Improvement in gastrointestinal dysfunction, such as dysphagia, gastroesophageal reflux, constipation

- Prevention, detection, and treatment of nutritional deficiencies, especially of micronutrients and vitamins

Most of the proposed options are based on indirect evidence. Adequately designed ad hoc studies are needed to provide evidence supporting current suggestions and hypotheses.

Acknowledgments: The authors thank Jennifer S. Hartwig, MD, for assistance in drafting the manuscript. This work was supported by the "Fondazione Grigioni per il Morbo di Parkinson."

Author Roles: All the authors significantly contributed to the work and approve the manuscript for submission. Study Design and Literature Review: Michela Barichella; Manuscript Drafting and Literature Review: Emanuele Cereda; Supervision, Review, and Critique: Gianni Pezzoli.

\section{REFERENCES}

1. Luchsinger JA, Gustafson DR. Adiposity and Alzheimer's disease. Curr Opin Clin Nutr Metab Care 2009;12:15-21.

2. Hu G, Jousilahti P, Nissinen A, Antikainen R, Kivipelto M, Tuomilehto J. Body mass index and the risk of Parkinson disease. Neurology 2006;67:1955-1099.

3. Abbott RD, Ross GW, White LR, et al. Midlife adiposity and the future risk of Parkinson's disease. Neurology 2002;59: 1051-1057.

4. Cereda E, Sansone V, Meola G, Malavazos AE. Increased visceral adipose tissue rather than BMI as a risk factor for dementia. Age Ageing 2007;36:488-491.

5. Chen H, Zhang SM, Schwarzschild MA, Hernán MA, Willett WC, Ascherio A. Obesity and the risk of Parkinson's disease. Am J Epidemiol 2004;159:547-555.

6. Kashihara K. Weight loss in Parkinson's disease. J Neurol 2006;253(Suppl 7):VII38-VII41.

7. Barichella M, Marczewska A, Vairo A, Canesi M, Pezzoli G. Is underweightness still a major problem in Parkinson's disease patients? Eur J Clin Nutr 2003;57:543-547.

8. Barichella M, Villa MC, Massarotto A, et al. Mini Nutritional Assessment in patients with Parkinson's disease: correlation between worsening of the malnutrition and increasing number of disease-years. Nutr Neurosci 2008;11:128-134.

9. White H, Pieper C, Schmader K. The association of weight change in Alzheimer's disease with severity of disease and mortality: a longitudinal analysis. J Am Geriatr Soc 1998;46: 1223-1227.

10. REAL.FR Group. Impact of nutritional status on the evolution of Alzheimer's disease and on response to acetylcholinesterase inhibitor treatment. J Nutr Health Aging 2005;9:75-80.

11. Ousset PJ, Nourhashemi F, Reynish E, Vellas B. Nutritional status is associated with disease progression in very mild Alzheimer disease. Alzheimer Dis Assoc Disord 2008;22:6671.

12. Uc EY, Struck LK, Rodnitzky RL, Zimmerman B, Dobson J, Evans WJ. Predictors of weight loss in Parkinson's disease. Mov Disord 2006;21:930-936.

13. Verbaan D, Marinus J, Visser M, van Rooden SM, Stiggelbout AM, van Hilten JJ. Patient-reported autonomic symptoms in Parkinson disease. Neurology 2007;69:333-341.

14. Fox SH, Lang AE. Levodopa-related motor complicationsPhenomenology. Mov Disord 2008;23(Suppl 3):S509-S514.

15. Cereda E, Valzolgher L, Pedrolli C. Mini nutritional assessment is a good predictor of functional status in institutionalised elderly at risk of malnutrition. Clin Nutr 2008;27: 700-705.

16. Schapira AHV. Parkinson's disease. BMJ 1999;318:311-314.

17. Quinn N. Parkinsonism-recognition and differential diagnosis. BMJ 1995;310:447-452.

18. Lorefält B, Ganowiak W, Wissing U, Granérus AK, Unosson M. Food habits and intake of nutrients in elderly patients with Parkinson's disease. Gerontology 2006;52:160-168. 
19. Markus HS, Cox M, Tomkins AM. Raised resting energy expenditure in Parkinson's disease and its relationship to muscle rigidity. Clin Sci (Lond) 1992;83:199-204.

20. Markus HS, Tomkins AM, Stern GM. Increased prevalence of undernutrition in Parkinson's disease and its relationship to clinical disease parameters. J Neural Transm Park Dis Dement Sect 1993;5:117-125

21. Kumru H, Santamaria J, Valldeoriola F, Marti MJ, Tolosa E. Increase in body weight after pramipexole treatment in Parkinson's disease. Mov Disord 2006;21:1972-1974.

22. Barichella M, Marczewska AM, Mariani C, Landi A, Vairo A, Pezzoli G. Body weight gain rate in patients with Parkinson's disease and deep brain stimulation. Mov Disord 2003;18: 1337-1340.

23. Macia F, Perlemoine C, Coman I, et al. Parkinson's disease patients with bilateral subthalamic deep brain stimulation gain weight. Mov Disord 2004;19:206-212.

24. Calabresi P, Di Filippo M, Ghiglieri V, Picconi B. Molecular mechanisms underlying levodopa-induced dyskinesia. Mov Disord 2008;23(Suppl 3):S570-S579.

25. Pare S, Barr SI, Ross SE. Effect of daytime protein restriction on nutrient intakes of free-living Parkinson's disease patients. Am J Clin Nutr 1992;55:701-707.

26. Barichella M, Marczewska A, De Notaris R, et al. Special low-protein foods ameliorate postprandial off in patients with advanced Parkinson's disease. Mov Disord 2006;21:1682_ 1687.

27. Logroscino G, Sesso HD, Paffenbarger RS Jr, Lee IM. Body mass index and risk of Parkinson's disease: a prospective cohort study. Am J Epidemiol 2007;166:1186-1190.

28. Chen H, O'Reilly EJ, Schwarzschild MA, Ascherio A. Peripheral inflammatory biomarkers and risk of Parkinson's disease. Am J Epidemiol 2008;167:90-95.

29. Hu G, Jousilahti P, Bidel S, Antikainen R, Tuomilehto J. Type 2 diabetes and the risk of Parkinson's disease. Diabetes Care 2007;30:842-847.

30. Simon KC, Chen H, Schwarzschild M, Ascherio A. Hypertension, hypercholesterolemia, diabetes, and risk of Parkinson disease. Neurology 2007;69:1688-1695.

31. Hu G, Antikainen R, Jousilahti P, Kivipelto M, Tuomilehto J. Total cholesterol and the risk of Parkinson disease. Neurology 2008;70:1972-1979

32. Driver JA, Smith A, Buring JE, Gaziano JM, Kurth T, Logroscino G. Prospective cohort study of type 2 diabetes and the risk of Parkinson's disease. Diabetes Care 2008;31:20032005.

33. Huang X, Abbott RD, Petrovitch H, Mailman RB, Ross GW. Low LDL cholesterol and increased risk of Parkinson's disease: prospective results from Honolulu-Asia Aging Study. Mov Disord 2008;23:1013-1018.

34. de Lau LM, Koudstaal PJ, Hofman A, Breteler MM. Serum cholesterol levels and the risk of Parkinson's disease. Am J Epidemiol 2006;164:998-1002.

35. Abbott RA, Cox M, Markus H, Tomkins A. Diet, body size and micronutrient status in Parkinson's disease. Eur J Clin Nutr 1992;46:879-884.

36. Lorefält B, Ganowiak W, Pålhagen S, Toss G, Unosson M, Granérus AK. Factors of importance for weight loss in elderly patients with Parkinson's disease. Acta Neurol Scand 2004; 110:180-187.

37. Chen H, Zhang SM, Hernán MA, Willett WC, Ascherio A. Weight loss in Parkinson's disease. Ann Neurol 2003;53:676679.

38. Levi S, Cox M, Lugon M, Hodkinson M, Tomkins A. Increased energy expenditure in Parkinson's disease. BMJ 1990;301:1256-1257.

39. Delikanaki-Skaribas E, Trail M, Wong WW, Lai EC. Daily energy expenditure, physical activity, and weight loss in Parkinson's disease patients. Mov Disord 2009;24:667-671.
40. Toth MJ, Fishman PS, Poehlman ET. Free-living daily energy expenditure in patients with Parkinson's disease. Neurology 1997;48:88-91.

41. Ross GW, Petrovitch H, Abbott RD, et al. Association of olfactory dysfunction with risk for future Parkinson's disease. Ann Neurol 2008;63:167-173.

42. Montaurier C, Morio B, Bannier S, et al. Mechanisms of body weight gain in patients with Parkinson's disease after subthalamic stimulation. Brain 2007;130:1808-1018.

43. Moro E, Scerrati M, Romito LM, Roselli R, Tonali P, Albanese A. Chronic subthalamic nucleus stimulation reduces medication requirements in Parkinson's disease. Neurology 1999;53:85-90.

44. Nirenberg MJ, Waters C. Compulsive eating and weight gain related to dopamine agonist use. Mov Disord 2006;21:524529.

45. Depression/Parkinson Italian Study Group. Pramipexole versus sertraline in the treatment of depression in Parkinson's disease: a national multicenter parallel-group randomized study. J Neurol 2006;253:601-607.

46. Bachmann CG, Trenkwalder C. Body weight in patients with Parkinson's disease. Mov Disord 2006;21:1824-1830.

47. Sirtori CR, Bolme P, Azarnoff DL. Metabolic responses to acute and chronic L-dopa administration in patients with parkinsonism. N Engl J Med 1972;287:729-733.

48. Davies KN, King D, Davies H. A study of the nutritional status of elderly patients with Parkinson's disease. Age Ageing 1994;23:142-145.

49. Lipman IJ, Boykin ME, Flora RE. Glucose intalerance in Parkinson's disease. J Chronic Dis 1974;27:573-579.

50. Sandyk R. The relationship between diabetes mellitus and Parkinson's disease. Int J Neurosci 1993;69:125-130.

51. Norman K, Pichard C, Lochs H, Pirlich M. Prognostic impact of disease-related malnutrition. Clin Nutr 2008;27:5-15.

52. Sato Y, Kaji M, Tsuru T, Oizumi K. Risk factors for hip fracture among elderly patients with Parkinson's disease. J Neurol Sci 2001;182:89-93.

53. Evatt ML, Delong MR, Khazai N, Rosen A, Triche S, Tangpricha V. Prevalence of vitamin D insufficiency in patients with Parkinson disease and Alzheimer disease. Arch Neurol 2008;65:1348-1352.

54. Nakayama $\mathrm{Y}$, Washio M, Mori M. Oral health conditions in patients with Parkinson's disease. J Epidemiol 2004;14:143-150.

55. Cersosimo MG, Benarroch EE. Neural control of the gastrointestinal tract: implications for Parkinson disease. Mov Disord 2008;23:1065-1075.

56. Lorefält B, Granérus AK, Unosson M. Avoidance of solid food in weight losing older patients with Parkinson's disease. J Clin Nurs 2006;15:1404-1412.

57. Müller J, Wenning GK, Verny M, et al. Progression of dysarthria and dysphagia in postmortem-confirmed parkinsonian disorders. Arch Neurol 2001;58:259-264.

58. Natale G, Pasquali L, Ruggieri S, Paparelli A, Fornai F. Parkinson's disease and the gut: a well known clinical association in need of an effective cure and explanation. Neurogastroenterol Motil 2008;20:741-749.

59. Alfonsi E, Versino M, Merlo IM, et al. Electrophysiologic patterns of oral-pharyngeal swallowing in parkinsonian syndromes. Neurology 2007;68:583-589.

60. Nagaya M, Kachi T, Yamada T, Igata A. Videofluorographic study of swallowing in Parkinson's disease. Dysphagia 1998; 13:95-100.

61. Bassotti G, Germani U, Pagliaricci S, et al. Esophageal manometric abnormalities in Parkinson's disease. Dysphagia 1998;13:28-31.

62. Gross RD, Atwood CW Jr, Ross SB, Eichhorn KA, Olszewski JW, Doyle PJ. The coordination of breathing and swallowing in Parkinson's disease. Dysphagia 2008;23:136145 . 
63. Lam K, Lam FK, Lau KK, et al. Simple clinical tests may predict severe oropharyngeal dysphagia in Parkinson's disease. Mov Disord 2007;22:640-644.

64. Manor Y, Giladi N, Cohen A, Fliss DM, Cohen JT. Validation of a swallowing disturbance questionnaire for detecting dysphagia in patients with Parkinson's disease. Mov Disord 2007;22:1917-1921.

65. Chou KL, Evatt M, Hinson V, Kompoliti K. Sialorrhea in Parkinson's disease: a review. Mov Disord 2007;22:2306-2313.

66. Wakabayashi K, Takahashi H, Takeda S, Ohama E, Ikuta F. Parkinson's disease: the presence of Lewy bodies in Auerbach's and Meissner's plexuses. Acta Neuropathol 1988;76: 217-221.

67. Braak H, de Vos RA, Bohl J, Del Tredici K. Gastric alphasynuclein immunoreactive inclusions in Meissner's and Auerbach's plexuses in cases staged for Parkinson's disease-related brain pathology. Neurosci Lett 2006;396:67-72.

68. Byrne KG, Pfeiffer R, Quigley EM. Gastrointestinal dysfunction in Parkinson's disease. A report of clinical experience at a single center. J Clin Gastroenterol 1994;19:11-16.

69. Soykan I, Lin Z, Bennett JP, McCallum RW. Gastric myoelectrical activity in patients with Parkinson's disease: evidence of a primary gastric abnormality. Dig Dis Sci 1999;44:927-931.

70. Goetze O, Nikodem AB, Wiezcorek J, et al. Predictors of gastric emptying in Parkinson's disease. Neurogastroenterol Motil 2006; 18:369-375.

71. Müller T, Erdmann C, Bremen D, et al. Impact of gastric emptying on levodopa pharmacokinetics in Parkinson disease patients. Clin Neuropharmacol 2006;29:61-67.

72. Davies KN, King D, Billington D, Barrett JA. Intestinal permeability and orocaecal transit time in elderly patients with Parkinson's disease. Postgrad Med J 1996;72:164-167.

73. Abbott RD, Petrovitch H, White LR, et al. Frequency of bowel movements and the future risk of Parkinson's disease. Neurology 2001;57:456-462.

74. Edwards L, Quigley EM, Hofman R, Pfeiffer RF. Gastrointestinal symptoms in Parkinson disease: 18-month follow-up study. Mov Disord 1993;8:83-86.

75. Ashraf W, Pfeiffer RF, Park F, Lof J, Quigley EM. Constipation in Parkinson's disease: objective assessment and response to psyllium. Mov Disord 1997;12:946-951.

76. Kupsky WJ, Grimes MM, Sweeting J, Bertsch R, Cote LJ. Parkinson's disease and megacolon: concentric hyaline inclusions (Lewy bodies) in enteric ganglion cells. Neurology 1987;37:1253-1255.

77. Ueki A, Otsuka M. Life style risks of Parkinson's disease: association between decreased water intake and constipation. J Neurol 2004;251(Suppl 7):vII18-vII23.

78. Singaram C, Ashraf W, Gaumnitz EA, et al. Dopaminergic defect of enteric nervous system in Parkinson's disease patients with chronic constipation. Lancet 1995;346:861864.

79. Cersosimo MG, Benarroch EE. Neural control of the gastrointestinal tract: implications for Parkinson disease. Mov Disord 2008;23:1065-1075.

80. Bushmann M, Dobmeyer SM, Leeker L, Perlmutter JS. Swallowing abnormalities and their response to treatment in Parkinson's disease. Neurology 1989;39:1309-1314.

81. Ciucci MR, Barkmeier-Kraemer JM, Sherman SJ. Subthalamic nucleus deep brain stimulation improves deglutition in Parkinson's disease. Mov Disord 2008;23:676-683.

82. Tison F, Wiart L, Guatterie M, et al. Effects of central dopaminergic stimulation by apomorphine on swallowing disorders in Parkinson's disease. Mov Disord 1996;11:729732 .

83. Born LJ, Harned RH, Rikkers LF, Pfeiffer RF, Quigley EMM. Cricopharyngeal dysfunction in Parkinson's disease: role in dysphagia and response to myotomy. Mov Disord 1996;11:5358 .
84. Restivo DA, Palmeri A, Marchese-Ragona R. Botulinum toxin for cricopharyngeal dysfunction in Parkinson's disease. N Engl J Med 2002;346:1174-1175.

85. Zangaglia R, Martignoni E, Glorioso M, et al. Macrogol for the treatment of constipation in Parkinson's disease. A randomized placebo-controlled study. Mov Disord 2007; 22:1239-1244.

86. Johanson JF. Review of the treatment options for chronic constipation. MedGenMed 2007;9:25.

87. Hamilton-Miller JM. Probiotics and prebiotics in the elderly. Postgrad Med J 2004;80:447-451.

88. Sullivan KL, Staffetti JF, Hauser RA, Dunne PB, Zesiewicz TA. Tegaserod (Zelnorm) for the treatment of constipation in Parkinson's disease. Mov Disord 2006;21:115-116.

89. Deane KH, Whurr R, Clarke CE, Playford ED, Ben-Shlomo Y. Non-pharmacological therapies for dysphagia in Parkinson's disease. Cochrane Database Syst Rev 2001;1:CD002816.

90. Logemann JA. Oropharyngeal dysphagia and nutritional management. Curr Opin Clin Nutr Metab Care 2007;10:611-614.

91. Coggrave M, Wiesel PH, Norton C. Management of faecal incontinence and constipation in adults with central neurological diseases. Cochrane Database Syst Rev 2006;2: CD002115.

92. Vemulapalli R. Diet and lifestyle modifications in the management of gastroesophageal reflux disease. Nutr Clin Pract 2008;23:293-298

93. Löser C, Aschl G, Hébuterne X, et al. ESPEN guidelines on artificial enteral nutrition--percutaneous endoscopic gastrostomy (PEG). Clin Nutr 2005;24:848-861.

94. Robbins J, Gensler G, Hind J, et al. Comparison of 2 interventions for liquid aspiration on pneumonia incidence: a randomized trial. Ann Intern Med 2008;148:509-518.

95. Troche MS, Sapienza CM, Rosenbek JC. Effects of bolus consistency on timing and safety of swallow in patients with Parkinson's disease. Dysphagia 2008;23:26-32.

96. Feinle-Bisset C, Horowitz M. Dietary factors in functional dyspepsia. Neurogastroenterol Motil 2006;18:608-618.

97. Little TJ, Horowitz M, Feinle-Bisset C. Modulation by high-fat diets of gastrointestinal function and hormones associated with the regulation of energy intake: implications for the pathophysiology of obesity. Am J Clin Nutr 2007;86:531-541.

98. Barclay AW, Petocz P, McMillan-Price J, et al. Glycemic index, glycemic load, and chronic disease risk-a meta-analysis of observational studies. Am J Clin Nutr 2008;87:627-637.

99. Kaltenbach T, Crockett S, Gerson LB. Are lifestyle measures effective in patients with gastroesophageal reflux disease? An evidence-based approach. Arch Intern Med 2006;166:965-971.

100. Goodwin VA, Richards SH, Taylor RS, Taylor AH, Campbell JL. The effectiveness of exercise interventions for people with Parkinson's disease: a systematic review and meta-analysis. Mov Disord 2008;23:631-640.

101. Olanow CW, Koller WC. An algorithm (decision tree) for the management of Parkinson's disease: treatment guidelines. American Academy of Neurology. Neurology 1998;50(3 Suppl 3):S1-S57.

102. Marczewska A, De Notaris R, Sieri S, Barichella M, Fusconi E, Pezzoli G. Protein intake in Parkinsonian patients using the EPIC food frequency questionnaire. Mov Disord 2006; 21:1229-1231.

103. Berry EM, Growdon JH, Wurtman JJ, Caballero B, Wurtman RJ. A balanced carbohydrate: protein diet in the management of Parkinson's disease. Neurology 1991;41:1295-1297.

104. Gaenslen A, Gasser T, Berg D. Nutrition and the risk for Parkinson's disease: review of the literature. J Neural Transm 2008;115:703-713.

105. Postuma RB, Espay AJ, Zadikoff C, et al. Vitamins and entacapone in levodopa-induced hyperhomocysteinemia: a randomized controlled study. Neurology 2006;66:1941-1943. 
106. Zoccolella S, Dell'aquila C, Abruzzese G, et al. Hyperhomocysteinemia in levodopa-treated patients with Parkinson's disease dementia. Mov Disord 2009;24:1028-1033.

107. Rodriguez-Oroz MC, Lage PM, Sanchez-Mut J, et al. Homocysteine and cognitive impairment in Parkinson's disease: A biochemical, neuroimaging, and genetic study. Mov Disord (in press).

108. Qualman SJ, Haupt HM, Yang P, Hamilton SR. Esophageal Lewy bodies associated with ganglion cell loss in achalasia.
Similarity to Parkinson's disease. Gastroenterology 1984;87: 848-856.

109. Parkinson Study Group. A randomized controlled trial of etilevodopa in patients with Parkinson disease who have motor fluctuations. Arch Neurol 2006;63:210-216.

110. Sofi F, Cesari F, Abbate R, Gensini GF, Casini A. Adherence to Mediterranean diet and health status: meta-analysis. BMJ 2008;337:a1344. 